\title{
Immunotherapy for pediatric brain tumors
}

\author{
Daniel B. Landi1,2, Eric M. Thompson ${ }^{1,2,3}$, David M. Ashley ${ }^{1,2,3}$ \\ 1Preston Robert Tisch Brain Tumor Center, Durham, NC 27710, USA. \\ ${ }^{2}$ Department of Pediatrics, Duke University Medical Center, Durham, NC 27710, USA \\ ${ }^{3}$ Department of Neurosurgery, Duke University Medical Center, Durham, NC 27710, USA.
}

Correspondence to: Dr. Daniel B. Landi, Department of Pediatrics, Duke University Medical Center, Durham, NC 27710, USA.

E-mail: daniel.landi@duke.edu

How to cite this article: Landi DB, Thompson EM, Ashley DM. Immunotherapy for pediatric brain tumors. Neuroimmunol Neuroinflammation 2018;5:29. http://dx.doi.org/10.20517/2347-8659.2018.35

Received: 8 Jun 2018 First Decision: 2 Jul 2018 Revised: 13 Jul 2018 Accepted: 16 Jul 2018 Published: 23 Jul 2018

Science Editor: Athanassios P. Kyritsis Copy Editor: Jun-Yao Li Production Editor: Huan-Liang Wu

\begin{abstract}
Immunotherapy, while effective against lymphoid cancers and some solid tumors, has shown less benefit against pediatric brain tumors. Tumor heterogeneity, a suppressive immune microenvironment, and the blood-brain barrier have the potential to diminish any immune-based approach and limit efficacy. More importantly, most pediatric brain tumors are immunologically quiescent, stemming from a low mutational burden. This review focuses on innate vs. adaptive immunotherapeutic approaches and describes how the immunologic context of pediatric brain tumors can help identify well-suited immunotherapies for our patients. In this framework, we will discuss past and current approaches using virotherapy, immunoconjugates, monoclonal antibodies, active immunization, and adoptive cellular therapy, and share our thoughts on how immunotherapy can cure children with brain tumors.
\end{abstract}

Keywords: Immunotherapy, brain tumor, pediatrics, virotherapy, active immunization, adoptive cellular therapy

\section{INTRODUCTION}

The incidence of pediatric brain tumors varies by country and ranges between 1-5 cases/100,000 persons, with about 4600 primary central nervous system tumors diagnosed in the United States annually ${ }^{[1,2]}$. There are over 100 histologic subtypes of brain tumors, but the most common diagnoses in children are low-grade gliomas, particularly pilocytic astrocytoma (incidence roughly 0.8/100,000) and medulloblastoma (incidence roughly $0.4 / 100,000)^{[2]}$. Outcomes for recurrent malignant brain tumors in children remain poor, and brain tumors are the leading cause of cancer death in children ${ }^{[3]}$. Even when effective, surgery, radiation, and chemotherapy cause neurologic and neurocognitive morbidity. Many children with brain tumors who survive

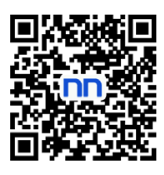


their disease have significant cognitive disability that limits their ability to live independently, progress fully in their education, or pursue a vocation ${ }^{[4]}$.

Immunotherapy attempts to leverage the high specificity of the immune system to target and eliminate cancer cells while leaving healthy cells undamaged. Chimeric antigen receptor (CAR) T cells and PD-1/PD-L1 monoclonal antibodies are the most impactful immunotherapies to date and have cured patients who otherwise had no curative option. Unfortunately, these successes have not significantly improved outcomes for most children with brain tumors. Understanding the immune environment in which pediatric brain tumors exist is requisite for identifying effective immune-based therapies for these diseases.

Historically, the blood-brain barrier and perceived sensitivity of deep midline structures to manipulation have limited investigators' ability to develop and deliver therapies for children with brain tumors. In the modern era, direct delivery methods, improved drug design, and surgical intervention involving brainstem and deep midline tumors drive the field forward. This review will indicate the routes whereby immunotherapies are delivered and mechanisms through which they selectively target the tumor, but will not unduly focus on the blood-brain barrier or tumor delivery methods.

\section{IMMUNOLOGICALLY "HOT” VS. "COLD” TUMORS AND MUTATIONAL LOAD}

"Hot" vs. "cold" tumors are distinguished by whether significant numbers of tumor infiltrating lymphocytes (TILs), most notably $\mathrm{T}$ cells, are present ${ }^{[5]}$. Functionally, $\mathrm{T}$ cells are potently cytolytic and are important for immunologic memory and surveillance to maintain an anti-tumor immune response ${ }^{[6]}$. $\mathrm{T}$ cell homing is influenced by activating cytokines, the tumor vasculature, integrins, and the presence of tumor-specific proteins, called "neoantigens" ${ }^{[5]}$. Hot tumors supply inflammatory cytokines and allow $\mathrm{T}$ cells permissive access within the tumor bed. Cold tumors lack $\mathrm{T}$ cell infiltration either because of a harshly immunosuppressive tumor microenvironment, or because the tumor is not inflammatory or exists in a strictly immuneprivileged site. Whereas the central nervous system (CNS) was formerly regarded as immune-privileged, this notion has been dispelled; immune cells are highly adept at reaching the CNS, even without blood brain barrier disruption $^{[7]}$.

In addition to inflammatory cytokines and permissive vasculature, hot tumors tend to exhibit a high number of neoantigens, which are novel peptide epitopes caused by mutations in the cancer genome. Non-synonymous mutations are changes in the cancer genome that produce an altered amino acid sequence that can drive tumorigenesis by altering cellular pathways or lead to expression of neoantigens ${ }^{[8]}$. Synonymous mutations do not change the amino acid sequence of an expressed gene but are not necessarily silent mutations. Synonymous mutations can serve as driver mutations by influencing translation, transcription, splicing, and mRNA transport ${ }^{[9]}$.

Melanoma and lung cancer are hot tumors that sometimes respond to immune checkpoint blockade ${ }^{[10,11]}$. Ultraviolet light in melanoma and smoke carcinogens in lung cancer induce DNA damage, and these tumors in older adults have accumulated higher numbers of non-synonymous mutations ${ }^{[8]}$. Pediatric cancers harbor few somatic mutations compared to adult tumors, and this is particularly true for pediatric brain tumors, which are almost always immunologically $\operatorname{cold}^{[12,13]}$. The lower tumor mutational load in pediatric brain tumors produces few neoantigens to stimulate $\mathrm{T}$ cell activation and proliferation within the tumor bed. Accordingly, an immunotherapy aimed at promoting an existing $\mathrm{T}$ cell immune response, such as checkpoint blockade, will be ineffective.

\section{DAMAGE RESPONSE AND TUMOR IMMUNITY}

Inflammation is an important component of an immune response. While the CNS is not an immune-priv- 
ileged site, regulatory immune cells and cytokines protect against excessive inflammation that would cause unacceptable inflammation involving the brain ${ }^{[14]}$. As brain tumors expand, local tissue damage and hypoxia induce regulatory cytokines and immune cells to quell inflammation and promote healing ${ }^{[15,16]}$. These factors contribute to the immunosuppressive behavior of the tumor itself and can blunt an anti-tumor immune response.

A typical endogenous immune response occurs in two phases. Pathogens, damaged DNA, cellular debris from apoptosis or necrosis, and inflammatory cytokines attract phagocytes, natural killer cells, and antigenpresenting cells as part of the innate immune response. Antigen-presenting cells then display peptide epitopes on MHC molecules, which engage T cells through their T cell receptor as part of the adaptive immune response.

Cells employ sophisticated DNA maintenance machinery to monitor and repair the genome, and damagesensing pathways are important for eliminating pre-cancerous and cancerous cells ${ }^{[17]}$. Conventional chemotherapy and radiation, as well as innate-based immunotherapies, induce DNA damage and cell death by either apoptosis or non-apoptotic pathways ${ }^{[14,18,19]}$. Cell death and DNA degradation produce molecules called damage-associated molecular patterns (DAMP), which are recognized by the innate immune system and promote an immune response. DNA damage-sensing machinery within the nucleus transmits this signal to the cytoplasm and activates stimulator of interferon genes (STING) to induce proinflammatory interferon signals, which can shift the immunosuppressive tumor bed toward a more inflammatory, anti-tumor state $^{[17]}$. DNA damage sensors also induce cell-surface ligand expression to recruit natural kill cells, natural killer T cells, and phagocytes to eliminate damaged cells and prime an adaptive immune response against the tumor $^{[20,21]}$.

In health, damage-sensing pathways preserve the integrity of the genome and recruit the immune system to eliminate damaged cells when needed. In many instances, tumors deactivate the cellular damage-sensing machinery, which allows immune evasion and can dampen the response to conventional therapies like radiation or immunotherapies that are directly cytotoxic ${ }^{[22]}$. In addition, mutations within the damage-sensing machinery itself can contribute to tumorigenesis ${ }^{[22]}$. In this way, tumors with high mutational loads are more likely to harbor deleterious mutations within damage-sensing genes. This explains, in part, why hypermutated tumors are often resistant to radiation and alkylating chemotherapy ${ }^{[23]}$.

Defective damage response pathways have implications for immunotherapy as well. Innate-based immunotherapies are typically inflammatory and attempt to kill target cells to increase tumor antigen exposure. Tumor cells that lack damage-sensing machinery and have defective death pathways will be less amenable to many innate-based immune responses. The ultimate goal of any immunotherapy is to create a $\mathrm{T}$ cell response targeting the entire tumor and generates immunologic memory to protect against recurrence. With this understanding how mutational load, tumor neoantigens, and DNA damage machinery affect tumor immunology, we will discuss approaches in each of the main areas of immunotherapy for pediatric brain tumors.

\section{VIROTHERAPY}

Virotherapy broadly refers to the use of viruses as therapeutic agents. Oncolytic viruses, which cause tumor cell death and can stimulate the immune system, are the most prominent clinical branch of virotherapy. Viruses are also useful as vectors for gene therapy, whereby viruses induce expression of a transgene that modifies the immune environment to promote an anti-tumor response. Retroviruses are used to genetically modify immune cells, most notably to express chimeric antigen receptors (CAR) on primary human T cells, and this will be discussed subsequently under adoptive cellular therapy. The last clinical branch of virotherapy, termed viral immunotherapy, uses viruses to introduce antigens that sensitize the host immune system 
to the tumor through cross-reactivity or as an adjuvant. Currently, clinical applications of virotherapy in pediatric brain tumors are limited to approaches using oncolytic viruses or viruses as gene transfer platforms.

\section{Oncolytic viruses}

Oncolytic viruses show promise in treating pediatric brain tumors. At least 50 clinical trials are ongoing using oncolytic viruses to treat cancer patients, mostly adults with non-CNS solid tumors. The oncolytic virus talimogene laherparepvec (TVEC), a modified type I herpes simplex virus for adults with advanced melano$\mathrm{ma}$, is the first oncolytic virus to receive FDA approval ${ }^{[24]}$. Mechanistically, oncolytic viruses predominantly function through a combination of tumor cell lysis and stimulation of the innate immune system through DAMP and pathogen-associated molecular patterns (PAMP $)^{[25]}$. Initially, oncolytic viruses were engineered for selective tumor tropism and direct cytotoxicity. However, oncolytic viruses are now regarded as immunotherapy for which efficacy depends on activating an endogenous anti-tumor immune response ${ }^{[26]}$.

TVEC enters tumor cells through nectin adhesion molecules and replicates within tumor cells that have dysfunctional anti-viral pathways ${ }^{[24]}$. The virus induces tumor cell death and causes DAMP and PAMP expression within the tumor. Additionally, the viral genome is genetically modified to increase MHC class I expression and to secrete GM-CSF, which promotes dendritic cell accumulation and antigen presentation to prime an adaptive immune response ${ }^{[24]}$. Taken together, this first-in-class agent represents how oncolytic viruses can be modified to stimulate innate immunity and readily combined with conventional and immunebased therapies. TVEC is undergoing clinical evaluation with checkpoint inhibitors and agents that target the MAP kinase pathway, which is activated in melanoma.

To date, at least five oncolytic viruses have been evaluated clinically in children with brain tumors: recombinant poliovirus ${ }^{[27,28]}$, adenovirus ${ }^{[29]}$, reovirus ${ }^{[30]}$, herpesvirus ${ }^{[31,32]}$, and new castle disease virus ${ }^{[33,34]}$.

PVSRIPO, is a recombinant, live attenuated, nonpathogenic oncolytic virus containing the oral poliovirus Sabin type 1 in which the internal ribosomal entry site (IRES) is replaced with the IRES from human rhinovirus. PVSRIPO is administered intratumorally for adults with recurrent glioblastoma via convection-enhanced delivery and enters cells expressing the poliovirus receptor, CD155, which is ubiquitously expressed on malignant glioma. PVSRIPO is directly cytotoxic and induces a marked inflammatory response. Interestingly, dendritic cells express CD155 and are infected by PVSRIPO. Whereas PVSRIPO lyses tumor cells expressing CD155, the virus induces interferon-dominant activation of dendritic cells and tumor-specific $\mathrm{CD} 8+\mathrm{T}$ cells ${ }^{[35]}$. PVSRIPO was well-tolerated in adults with recurrent glioblastoma (GBM) with some encouraging responses ${ }^{[36]}$ and is being evaluated in a phase II trial in adults with recurrent GBM in combination with lomustine. PVSRIPO is also being used to treat children with recurrent supratentorial malignant glioma as a phase $\mathrm{Ib}_{\text {trial }}{ }^{[28]}$.

Currently, three other early-phase trials using oncolytic viruses are ongoing for children with brain tumors. HSV G207, a modified type 1 herpesvirus, is delivered intratumorally to children with recurrent or progressive supratentorial malignant brain tumors. HSV G207 is cytotoxic and replicates within infected cells, then infects neighboring cells following cell lysis. Subsequent cohorts of patients will receive a single dose of radiation, which has been shown to increase viral activity in pre-clinical studies and was well-tolerated in an adult phase I trial ${ }^{[37]}$. Wild-type reovirus preferentially infects and kills cancer cells in its unmodified form ${ }^{[38]}$ and induces an interferon-dominant immune response following intravenous administration in adults with brain tumors ${ }^{[39]}$. Reovirus is being evaluated in combination with GM-CSF in children with recurrent malignant brain tumors ${ }^{[30]}$. Newcastle disease virus (NDV) also induces selective tumor cell death and stimulates the innate immune system. NDV has been used clinically in cancer patients for decades with scattered clinical responses ${ }^{[40]}$. Currently, NDV is administered intratumorally in children with diffuse intrinsic brainstem glioma to induce tumor lysis. Tumor antigens are then harvested systemically and used to prime autologous 
Table 1. Virotherapy trials for pediatric brain tumors

\begin{tabular}{|c|c|c|}
\hline Trial/therapy & Description & NCT/reference \\
\hline $\begin{array}{l}\text { Recombinant poliovirus, } \\
\text { PVSRIPO }\end{array}$ & $\begin{array}{l}\text { Phase Ib trial evaluating PVSRIPO in children with recurrent supratentorial malignant } \\
\text { glioma }\end{array}$ & $\begin{array}{l}\text { NCT03043391 } \\
{[27]}\end{array}$ \\
\hline $\begin{array}{l}\text { Modified type I herpesvirus, } \\
\text { HSV G207 }\end{array}$ & $\begin{array}{l}\text { Phase } 1 \text { trial evaluating HSV G207 alone or with single radiation dose in children with } \\
\text { recurrent supratentorial malignant brain tumors }\end{array}$ & $\begin{array}{l}\text { NCT02457845 } \\
{[32]}\end{array}$ \\
\hline Wild-type reovirus & $\begin{array}{l}\text { Phase I trial evaluating reovirus in combination with GM-CSF in children with recurrent } \\
\text { malignant brain tumors }\end{array}$ & $\begin{array}{l}\text { NCT02444546 } \\
{[30]}\end{array}$ \\
\hline Newcastle disease virus & $\begin{array}{l}\text { Phase I trial evaluating newcastle disease virus in combination with autologous DC in } \\
\text { children with brainstem glioma }\end{array}$ & [33] \\
\hline $\begin{array}{l}\text { Modified adenovirus, } \\
\text { Ad-RTS-hIL-12 }\end{array}$ & $\begin{array}{l}\text { Phase I trial evaluating Ad-RTS-hIL-12, a vector for viral gene therapy, in children with } \\
\text { progressive supratentorial tumors and diffuse intrinsic pontine glioma }\end{array}$ & $\begin{array}{l}\text { NCT03330197 } \\
{[47]}\end{array}$ \\
\hline
\end{tabular}

dendritic cells ${ }^{[34]}$.

\section{Viral gene therapy}

Viruses are highly adept at introducing foreign genes and utilizing host machinery for protein expression. The human genome contains a large number of endogenous retroviral sequences, and roughly $8 \%$ of the human genome derives from infectious retroviruses ${ }^{[41]}$. Retroviruses, which predominantly infect dividing cells and stably integrate into the host genome, are useful for viral gene therapy. The lentivirus genus of retroviruses can transduce slowly-dividing or quiescent cells, overcoming in part the limitation that retroviruses must transduce dividing cells ${ }^{[42]}$. In cancer immunotherapy, retroviral transduction is typically performed ex vivo to genetically modify immune cells and not to deliver a direct therapeutic benefit.

Toca-511, however, uses a retroviral replicating vector to selectively transduce cancer cells with a yeast-derived cytosine deaminase gene following intratumoral administration. The prodrug 5 -fluorocytosine is given systemically and selectively converted fluorouracil (5-FU) in tumor cells expressing cytosine deaminase. This platform illustrates how viruses are useful as a form of gene therapy and has shown clinical efficacy in adults with glioblastoma. Toca-511 has been studied preclinically in medulloblastoma models and has a strong rationale for clinical evaluation in children ${ }^{[43]}$.

Compared to retroviruses, adenoviruses more readily transduce non-dividing cells ${ }^{[44]}$. Adenovirus vectors typically have smaller DNA capacity and are more immunogenic, which can limit gene expression in vivo ${ }^{[45]}$. One adenovirus gene therapy platform is being evaluated clinically in children with brain tumors: The modified adenovirus, Ad-RTS-hIL-12, is injected intratumorally and uses an oral activator ligand to toggle IL-12 expression within the tumor. In early phase adult studies in recurrent GBM, this platform was well-tolerated, and preliminary data showed correlation between tumor response and IL-12 secretion ${ }^{[46]}$. Ad-RTS-hIL-12 is being evaluated in children with progressive supratentorial tumors and diffuse intrinsic pontine glioma ${ }^{[47]}$. Table 1 lists notable virotherapy trials for pediatric brain tumors.

\section{MONOCLONAL ANTIBODIES AND IMMUNOCONJUGATES}

Similar to oncolytic viruses and tumor-directed viral gene therapy, monoclonal antibodies $(\mathrm{mAb})$ and immunoconjugates can be used as immunotherapy to elicit an innate immune response. MAb directed against tumor-specific antigens have varied mechanisms of action, which are often incompletely understood, even in clinically effective products. For example, the HER2-specific mAb trastuzumab improves survival in patients with advanced HER2-positive breast cancer and is FDA approved in this disease ${ }^{[48]}$. Several anti-tumor mechanisms of trastuzumab have been identified, including antibody-dependent cell-mediated cytotoxicity (ADCC) involving Fc receptors on phagocytes ${ }^{[49]}$, inhibition of HER2 signaling ${ }^{[50,51]}$, and downregulation of HER2 cell-surface expression ${ }^{[51]}$. 
There are two main ways mAbs can promote an immune response: ADCC and immune modulation. MAbs can trigger ADCC, in which cells of the innate immune system, specifically NK cells and phagocytes, lyse a tumor cell coated with antibodies containing Fc regions. There are no mAbs for primary brain tumors that function primarily by ADCC. Bevacizumab is a $\mathrm{mAb}$ that inhibits angiogenesis by binding to vascular endothelial growth factor (VEGF), a pro-angiogenesis cytokine. Bevacizumab is not strictly an immunotherapy but may have immunomodulatory effects, such as enhanced $\mathrm{T}$ cell recruitment and dendritic cell maturation and migration related to an inhibitory VEGF effect ${ }^{[52]}$. Bevacizumab is effective in some children with recurrent low-grade glioma ${ }^{[53]}$ and FDA approved for recurrent GBM in adults ${ }^{[54]}$, but is not immunotherapy in the sense that it does not elicit an anti-tumor immune response. Similarly, monoclonal antibodies recognizing epidermal growth factor receptor (EGFR), block EGFR signaling in tumor cells and may, to a lesser extent, promote ADCC. Erlotinib, an anti-EGFR $\mathrm{mAb}$, is ineffective against recurrent pediatric malignant glioma ${ }^{[55]}$ and ependymoma ${ }^{[56]}$. Newer generation EGFR mAbs have been developed with improved ADCC characteristics but have not been evaluated in pediatric brain tumors ${ }^{[57]}$.

\section{Immunomodulatory monoclonal antibodies}

MAbs can also promote anti-tumor immunity through immune modulation. Checkpoint inhibitors are an example of this and will be discussed separately. CD40 is a TNF receptor superfamily member expressed broadly on dendritic cells, B cells, and monocytes, as well as some tumor cells. Binding to the natural ligand CD40L expressed on $\mathrm{T}$ helper cells causes immune cell activation ${ }^{[58]}$. Agonistic CD40 mAbs activate antigen presenting cells and cytotoxic myeloid cells ${ }^{[59]}$ and have induced clinical responses in adults with lymphoid tumors $^{[58]}$. The CD40 agonistic antibody APX005M, delivered intravenously, is being evaluated in a phase I trial for children with recurrent malignant brain tumors and newly diagnosed diffuse intrinsic pontine glioma ${ }^{[60]}$.

CD47 is an integrin-associated protein ubiquitously expressed on human cells. In the context of tumor immunology, CD47 serves as a "don't-eat-me" signal for macrophages ${ }^{[61]}$. The anti-CD47 mAb Hu5F9-G4 currently is in early phase trials for adults with lymphoid and non-CNS solid tumors. While not yet used clinically for primary brain tumors, Hu5F9-G4 has shown promising preclinical activity in vivo against orthotopic xenograft models of malignant pediatric brain tumors ${ }^{[62]}$.

\section{Immunoconjugates}

Several immunoconjugates have reached the clinic in pediatric brain tumors as a form of immunotherapy. Immunoconjugates consist of an antibody fragment joined to some sort of effector molecule. Examples of effector molecules include immunotoxins, radioisotopes, and immune ligands. Immunoconjugates using immunotoxins are most prevalent and are typically comprised of a toxin coupled to a single-chain variableregion antibody fragment ( $\mathrm{scFv}$ ) that binds a tumor antigen. As a class, immunoconjugates typically have a short half-life following administration and are given directly into the tumor by convection enhanced delivery.

The EGFR gene is frequently amplified in adult GBM but not in pediatric GBM ${ }^{[63]}$. However, most pediatric glial tumors overexpress EGFR, making it an attractive target for immunotherapy for pediatric brain tumors $^{[63]}$. D2C7-IT is an immunoconjugate comprised of a scFv that recognizes for both wild-type EGFR and the deletion variant EGFRvIII fused to the pseudomonal exotoxin PE38KDEL ${ }^{[64]}$. Upon binding EGFR, D2C7-IT is internalized and inhibits protein synthesis and causes tumor cell death. In a phase 1 trial in adults with malignant glioma, D2C7-IT induces inflammation within the tumor bed and has produced some clinical responses ${ }^{[65]}$. D2C7-IT will be evaluated in a phase I trial in children with recurrent, EGFR-positive malignant glioma at Duke.

Podoplanin is a tumor-associated glycoprotein highly expressed on pediatric malignant glioma and medulloblastoma ${ }^{[66]}$. A recombinant anti-podoplanin immunotoxin containing the pseudomonal exotoxin is effec- 
Table 2. Immunomodulatory mAb and immunoconjugate trials in pediatric brain tumors

\begin{tabular}{lll}
\hline Trial/therapy & \multicolumn{1}{c}{ Description } & NCT/reference \\
\hline Agonistic CD40 mAb, APX005M & Phase I trial for children with recurrent malignant brain tumors and & NCT03389802 \\
& newly diagnosed diffuse intrinsic pontine glioma & {$[60]$} \\
B7-H3 directed radioisotope, 124I-8H9 & Phase I trial for children with diffuse intrinsic pontine glioma & NCT01502917 \\
& & {$[71]$} \\
\hline
\end{tabular}

tive in preclinical pediatric brain tumor models but has not reached the clinic ${ }^{[66]}$. Immunoconjugates bearing a pseudomonal exotoxin that the IL-4 receptor ${ }^{[67]}$, IL-13 receptor ${ }^{[68]}$, or tumor growth factor alpha (TGF $\left.\alpha\right)^{[69]}$ were safe following direct administration into the tumor and intermittently effective in early-phase studies but have not been evaluated in children.

Immunoconjugates can also induce tumor death and anti-tumor immunity using radioisotopes, referred to as radioimmunotherapy. To date, only one radioisotope immunoconjugate has been used to treat primary pediatric brain tumors. ${ }^{124} \mathrm{I}-8 \mathrm{H} 9$ contains a scFv recognizing the $\mathrm{B} 7-\mathrm{H} 3$ antigen, expressed on glial tumors but not healthy cells, coupled to a radioactive iodine isotope ${ }^{[70]} \cdot{ }^{124} \mathrm{I}-8 \mathrm{H} 9$ is being evaluated as a phase I trial for children with diffuse intrinsic pontine glioma and is administered intratumorally ${ }^{[7]}$.

Lastly, immunoconjugates incorporating an immune-activating ligand, also called bispecific antibodies, are being explored. Blinatunomab is a bispecific molecule that recognizes CD19, expressed on immature B cells, and $\mathrm{CD} 3$, which engages $\mathrm{T}$ cells. This $\mathrm{T}$ cell-engaging molecule induces remission in relapsed, immature Blineage leukemia and is FDA approved for this disease ${ }^{[72]}$. Investigators at Duke developed a fully human, bispecific antibody (hEGFRvIII-CD3 bi-scFv) that redirects human T cells to kill EGFRvIII-positive malignant glioma cells ${ }^{[73]}$. This product is being evaluated in adults but is less useful for children with malignant glioma, as less than $5 \%$ of malignant glioma in children expresses EGFRvIII ${ }^{[74]}$. Table 2 lists current immunomodulatory $\mathrm{mAb}$ and immunoconjugate trials in pediatric brain tumors.

\section{IMMUNE CHECKPOINT INHIBITORS}

Initial clinical evaluation of PD-1 and PD-L1 monoclonal antibodies demonstrated response rates of around $25 \%$ in adults with relapsed/refractory solid tumors ${ }^{[75,76]}$. Patients rarely had complete or sustained responses, but these encouraging results prompted evaluation checkpoint inhibitors in brain tumors. Unfortunately, these agents have been largely ineffective for most patients with brain tumors ${ }^{[77]}$.

A growing number of immune checkpoints are being targeted clinically, but mAbs targeting the PD-1/PDL1 immune checkpoint remain the most widely used. Activated T cells express PD-1, a member of the CD28 family which impairs $\mathrm{T}$ cell activation and promotes $\mathrm{T}$ cell anergy and apoptosis ${ }^{[78]}$. PD-L1, which is expressed ubiquitously on solid tumors and also on regulatory immune cells within the tumor bed, binds PD-1 to dampen an anti-tumor $\mathrm{T}$ cell response ${ }^{[79,80]}$. Blocking this interaction using a mAb binding either PD-1 or PD-L1 can promote anti-tumor T cell activity.

In order for checkpoint inhibition to be optimally effective, the tumor must be immunologically hot, with $\mathrm{T}$ cell infiltration and tumor antigens that can be recognized by $\mathrm{T}$ cells. Tumor mutational load and $\mathrm{T}$ cell infiltration within the tumor are highly predictive for response with checkpoint inhibitor ${ }^{[8,82]}$. In melanoma and lung cancer, tumor mutational burden, which impacts the number of neoantigens and T-cell immunogenicity, correlate with response to checkpoint blockade ${ }^{[8,83]}$.

Hypermutant pediatric GBM, while rare, responds to anti-PD-1 checkpoint blockade. Two children with biallelic mismatch repair deficiency and hypermutated recurrent GBM responded to nivolumab ${ }^{[13]}$. These data are similar to those reported in adults with hypermutated colorectal carcinoma who received pembrolizumab, a PD-1 checkpoint inhibitor ${ }^{[84]}$. 
Most often, pediatric brain tumors harbor fewer mutations compared to adult tumors, which have a lower mutational load than most solid tumors ${ }^{[13,85]}$. In a large analyses from over 300 adult glioma samples, less than $4 \%$ of tumors had a high tumor mutational load ${ }^{[86]}$. Even rare tumors that were hypermutated did not have significant $\mathrm{T}$ cell infiltration within the tumor. Taken together, these data explain at least in part why checkpoint blockade as monotherapy is unlikely to be impactful for pediatric brain tumors.

CheckMate 143 was a phase III randomized trial to evaluate efficacy of nivolumab, an anti-PD-1 monoclonal antibody compared to bevacizumab in adults with recurrent GBM. Nivolumab did not improve overall survival compared to bevacizumab ${ }^{[77]}$. Two additional trials of combing nivolumab and radiation with or without temozolomide in patients with newly-diagnosed, MGMT-unmethylated ${ }^{[87]}$ and MGMT-methylated ${ }^{[88]}$ GBM are ongoing.

While there have been no completed studies evaluating efficacy of checkpoint inhibitors in pediatric brain tumors, a number of trials are ongoing, including PD-1 antibodies as monotherapy or in combination with a CTLA-4 antibodies, and another checkpoint inhibitor against indoleamine (2,3)-dioxygenase (IDO). However, based on the disappointing results in CheckMate 143 and more recently for an IDO inhibitor in large phase III trial ${ }^{[89]}$, these agents are likely to be more effective in combination with immunotherapies which cause inflammation and promote $\mathrm{T}$ cell infiltration and activation first.

\section{ACTIVE IMMUNIZATION}

Active immunization therapies deliver an immune stimulus to trigger an endogenous anti-tumor response. Typically, a vaccine is administered to stimulate and direct the host immune system to target antigens on the tumor. Cancer vaccines are a promising area of immunotherapy and are typically well tolerated. Vaccines containing tumor antigens, such as peptides, tumor lysate, or nucleic acids, and autologous dendritic cells are the most common approaches used clinically for patients with brain tumors. The intent of any active immunization strategy is to trigger an anti-tumor $\mathrm{T}$ cell response. $\mathrm{T}$ cell activation optimally occurs when $\mathrm{T}$ cells recognize antigen displayed on MHC molecules of antigen presenting cells in the setting of inflammation. Accordingly, active immunization approaches are designed to cause inflammation and antigen uptake by antigen presenting cells in lymphoid tissues, most often in lymph nodes.

\section{Dendritic cell vaccines}

Dendritic cells (DC) are a critical link between the innate and adaptive immune systems. Upon encountering foreign antigens, specifically pathogen-associated molecular patterns, DC release inflammatory cytokines that activate the innate immune system. DC also process and present antigens to $\mathrm{T}$ cells and B cells, thereby activating naïve, effector, and memory immune cells or maintaining tolerance against self-antigens ${ }^{[00]}$.

Most commonly, DC for active immunization are generated by isolating monocytes from cancer patients that are expanded and activated ex vivo. These DC are loaded with either tumor lysate, peptides, nucleic acids, or viral epitopes that are expressed by the tumor. DC are usually matured with GM-CSF, then administered as a vaccine. Adjuvants such as tetanus toxoid are important to improve inflammation and immunogenicity in the host ${ }^{[90]}$.

Clinical testing of DC vaccines has demonstrated modest yet encouraging results in patients with advanced cancers ${ }^{[91,92]}$. There is general consensus that $\mathrm{DC}$ vaccines can induce tumor-specific $\mathrm{T}$ cell responses and immunological memory, and this is a promising platform for pediatric brain tumors ${ }^{[92]}$. To date, there have been several trials using autologous DC vaccines loaded with tumor $\mathrm{RNA}^{[93]}$ or tumor lysate ${ }^{[94-96]}$ for children with brain tumors. At this juncture, DCs are reliably manufactured and extremely well-tolerated. However, to improve efficacy, strategies to improve targeting, antigen loading, and migration in vivo are needed. 
One of the central challenges for any active immunization approach is how to elicit an immune response against relatively weak "self" tumor antigens. Interestingly, cytomegalovirus (CMV) nucleic antigens are ubiquitously expressed in human malignant glioma ${ }^{[97]}$, and an adult patient treated with a DC vaccine pulsed with GBM tumor lysate developed a robust $\mathrm{T}$ cell response against the CMV antigen $\mathrm{pp} 65^{[98]}$. The relative ease of eliciting an immune response against viral antigens contrasts with the difficulty of immunization against "self" tumor antigens and makes CMV an attractive target for immunotherapy. Dendritic cells targeting pp65 lead to long-term survival in small numbers of adults with newly diagnosed $\mathrm{GBM}^{[99]}$, and survival correlated with DC migration in a CCL3-depedant fashion ${ }^{[100]}$. This DC platform targeting CMV antigens will be evaluated in children with malignant glioma and recurrent medulloblastoma at Duke.

\section{Peptide vaccines}

Manufacturing DC vaccines is costly, and poor DC migration following administration remains a challenge. Accordingly, active immunization strategies that stimulate endogenous DC activation are appealing, such as peptide vaccines, which inject tumor peptides with adjuvants, usually adjacent to lymph nodes. A few peptide vaccines for children with brain tumors are in early phase testing. One trial using a peptide vaccine targeting the H3.K27M neoantigen for HLA-A2+ children with H3K27M mutated glioma is underway ${ }^{[101]}$. A second peptide trial targeting the CMV epitopes pp65 and glycoprotein B is also underway for children with recurrent malignant glioma and medulloblastoma ${ }^{[102]}$. Additionally, a peptide trial using glioma-associated antigens for HLA-A2+ children with malignant brainstem and non-brainstem gliomas, including low-grade glioma, is underway ${ }^{[103]}$. This platform has been well tolerated and effective at generating an anti-tumor immune respons ${ }^{[104]}$. At least four children with progressive, low-grade glioma have had sustained partial responses, providing evidence that peptide vaccines, typically given with Montanide adjuvant, can generate an endogenous anti-tumor response ${ }^{[105]}$. Montanide is a water-in-oil emulsion that acts as an adjuvant in these vaccines by enhancing $\mathrm{CD} 4+$ and $\mathrm{CD} 8+\mathrm{T}$ cell response against antigens in the vaccine ${ }^{[106]}$.

Recently, highly personalized, neoantigen vaccines are gaining momentum. Initial clinical studies with cancer vaccines used whole tumor lysates, which contain a mixture of self-antigens and undefined neoantigens. These vaccines elicited broad immune responses but were generally ineffective. Using next-generation sequencing to identify DNA and RNA sequences of neoantigens and advanced algorithms to predict MHC I and MHC II loading, vaccines can be created that target specific neoantigens and hold promise for improving outcomes ${ }^{[92]}$. This personalized neoantigen approach was effective in some advanced melanoma patients, and combination with checkpoint blockade expanded the repertoire of neoantigen-specific $\mathrm{T}$ cells and further improved efficacy ${ }^{[107]}$. Table 3 lists notable past and current active immunization trials for pediatric brain tumors.

\section{ADOPTIVE CELLULAR THERAPY}

Adoptive cellular therapy (ACT) involves manipulating effector immune cells ex vivo before transfer back to a patient with cancer. Initially, ACT for brain tumors used tumor-infiltrating lymphocytes (TIL) harvested from the tumor bed or immune cells isolated from peripheral blood or lymph nodes. Following collection, autologous lymphocytes were stimulated with cytokines or tumor antigen and infused back into patients. Overall, ACT using TILs or peripheral lymphocytes was well-tolerated but clinically ineffective, although immune activation and some responses were reported ${ }^{[108,109]}$. Natural killer $\mathrm{T}$ cells, which are specialized, CD1d-restricted $\mathrm{T}$ cells, recognize lipid antigens and have been tested in melanoma, but not brain tumors ${ }^{[110]}$.

By far, the most prominent type of adoptive cellular therapy involves cytotoxic $\mathrm{T}$ cells that are genetically modified to express a chimeric antigen receptor (CAR). CARs are synthetic receptors containing an antigenbinding domain, typically derived from the short chain variable fragment ( $\mathrm{scFv}$ ) of an antibody, coupled to the zeta chain and cytolytic machinery of a $\mathrm{T}$ cell receptor. Using retroviral vectors, primary human $\mathrm{T}$ cells 
Table 3. Notable past and ongoing active immunization trials for pediatric brain tumors

\begin{tabular}{|c|c|c|}
\hline Trial/therapy & Description & Reference \\
\hline $\begin{array}{l}\text { Monocyte-derived DCs loaded } \\
\text { with tumor RNA }\end{array}$ & Phase I trial evaluating DCs pulsed with tumor RNA in children with brain tumors & [93] \\
\hline $\begin{array}{l}\text { Monocyte-derived DC loaded } \\
\text { with whole tumor lysate }\end{array}$ & $\begin{array}{l}\text { Phase I trial evaluating DCs pulsed with whole tumor lysate in children and adults } \\
\text { with relapsed malignant glioma }\end{array}$ & {$[94]$} \\
\hline $\begin{array}{l}\text { Monocyte-derived DC loaded } \\
\text { with whole tumor lysate }\end{array}$ & $\begin{array}{l}\text { Phase I trial with DC pulsed with tumor lysate for children with newly diagnosed or } \\
\text { recurrent high-grade gliomas }\end{array}$ & [95] \\
\hline $\begin{array}{l}\text { Monocyte-derived DC loaded } \\
\text { with whole tumor lysate }\end{array}$ & $\begin{array}{l}\text { Phase I trial with postoperative DC loaded with tumor lysate for children and adults } \\
\text { with recurrent GBM }\end{array}$ & {$[96]$} \\
\hline $\begin{array}{l}\text { Peptide vaccine targeting } \\
\text { H3.K27M }\end{array}$ & $\begin{array}{l}\text { Phase I trial evaluating peptide vaccine targeting H3.K27M neoantigen for HLA-A2+ } \\
\text { children with } \mathrm{H} 3 \mathrm{~K} 27 \mathrm{M} \text { mutated glioma }\end{array}$ & $\begin{array}{l}\text { NCT02960230 } \\
{[101]}\end{array}$ \\
\hline $\begin{array}{l}\text { Peptide vaccine targeting CMV } \\
\text { epitopes pp } 65 \text { and glycoprotein B }\end{array}$ & $\begin{array}{l}\text { Phase I trial evaluating peptide vaccine targeting CMV pp65 and glycoprotein B for } \\
\text { children with recurrent malignant glioma and medulloblastoma }\end{array}$ & $\begin{array}{l}\text { NCT03299309 } \\
{[102]}\end{array}$ \\
\hline $\begin{array}{l}\text { Peptide vaccine targeting glioma } \\
\text { antigens }\end{array}$ & $\begin{array}{l}\text { Phase I peptide trial using glioma-associated antigens for HLA-A2+ children with } \\
\text { malignant brainstem and non-brainstem gliomas, including low-grade glioma }\end{array}$ & $\begin{array}{l}\text { NCT01130077 } \\
{[103]}\end{array}$ \\
\hline
\end{tabular}

are genetically modified to express the CAR molecule, which is designed to bind a tumor-restricted antigen and cause tumor cell death.

The CD19 CAR, which is effective against B-lineage lymphoid malignancies ${ }^{[111,112]}$, is FDA approved and induces remission in most patients with relapsed CD19-positive leukemia. CAR T cells targeting HER2 ${ }^{[113]}$, IL13ra2 ${ }^{[114]}$, EGFRvIII ${ }^{[115]}$, and EphA2 ${ }^{[116]}$ have been used to treat adults with GBM. A trial involving CMVspecific cytotoxic T lymphocytes expressing a HER2 CAR treated seven children with GBM. There were no serious adverse events or instances of cytokine release syndrome, and at least one child had a partial response $^{[113]}$. Transient responses following adoptive CAR $\mathrm{T}$ cell therapy are not infrequent, but almost all patients ultimately suffer disease progression.

There are multiple reasons the success of the CD19 CAR for B-lymphoblastic leukemia has not been duplicated by CAR T cells for brain tumors. The CD19 CAR targets an antigen that is ubiquitous and expressed solely on tumor cells or non-essential B cells without a strongly immunosuppressive tumor bed. Additionally, the CD19 single chain variable fragment (scFv) that guides the CAR T cell imparts an optimal activation profile and supports continued T cell killing ${ }^{[117]}$. This characteristic of the scFv is a key and unique distinction in this $\mathrm{T}$ cell product. ScFvs for other CAR T cells cause tonic signaling, which can cause $\mathrm{T}$ cell exhaustion and limits anti-tumor activity in patients following adoptive transfer ${ }^{[117]}$.

Antigen escape, tumor heterogeneity, and a harshly immunosuppressive immune microenvironment also contribute to treatment failure by CAR T cells. In a recently completed phase I trial for adults with recurrent GBM, EGFRvIII CAR T cells reliably reached the tumor bed following peripheral administration. However, ex vivo analyses from resected tumor showed dramatic adaptive resistance, with markedly increased PDL1 expression and an influx of regulatory $\mathrm{T}$ cells, as well as decreased expression of the targeted EGFRvIII antigen $^{[115]}$.

\section{CONCLUSIONS}

Immunotherapy holds tremendous promise for improving outcomes for children with brain tumors. While checkpoint inhibitors and CAR T cells are well suited for hypermutated, immunologically hot tumors and B-cell malignancies, respectively, these modalities are less of a fit for pediatric brain tumors. Rather, immunotherapy approaches that induce inflammation and an innate immune response may be a better starting point, on which checkpoint agents and other $\mathrm{T}$ cell-directed agents can build.

While we are optimistic about immunotherapy in pediatric neuro-oncology, it is important to recognize that conventional chemotherapy and radiation will likely retain a role in treatment, particularly as both of these 
modalities can be immunomodulatory and useful for shifting the immune balance toward anti-tumor immunity. Advanced surgical practice, radiation, and chemotherapy, including novel, targeted agents, remain important tools for treating our pediatric patients. It is important to point out that the most impactful treatment for brain tumors in the last decade is probably not an immunotherapy; BRAF and MEK inhibitors targeting the MAP kinase pathway, which is constitutively overactive in pilocytic astrocytoma and a fraction of other glial tumors, are radically changing how these diseases are treated and improving outcomes ${ }^{[118]}$. Taken together, the immunological context and molecular pathogenesis of each child's tumor must be considered on a case-by-case basis in determining any therapy, particularly in deciding what type of immunotherapy is most likely to add benefit.

\section{DECLARATIONS}

\section{Authors' contributions}

Design: Landi D, Ashley D

Literature research, manuscript writing, editing, and revision: Landi D, Thompson E, Ashley D

\section{Availability of data and materials}

Not applicable.

\section{Financial support and sponsorship}

None.

\section{Conflicts of interest}

The authors declare that there are no conflicts of interest.

\section{Ethical approval and consent to participate}

Not applicable.

\section{Consent for publication}

Not applicable.

\section{Copyright}

(c) The Author(s) 2018.

\section{REFERENCES}

1. Ostrom QT, Gittleman H, Xu J, Kromer C, Wolinsky Y, Kruchko C, Barnholtz-Sloan JS. CBTRUS statistical report: primary brain and other central nervous system tumors diagnosed in the United States in 2009-2013. Neuro Oncol 2016;18:v1-75.

2. Johnson KJ, Cullen J, Barnholtz-Sloan JS, Ostrom QT, Langer CE, Turner MC, McKean-Cowdin R, Fisher JL, Lupo PJ, Partap S, Schwartzbaum JA, Scheurer ME. Childhood brain tumor epidemiology: a brain tumor epidemiology consortium review. Cancer Epidemiol Biomarkers Prev 2014;23:2716-36.

3. Noone AM, Howlader N, Krapcho M, Miller D, Brest A, Yu M, Ruhl J, Tatalovich Z, Mariotto A, Lewis DR, Chen HS, Feuer EJ, Cronin KA. SEER Cancer Statistics Review, 1975-2015. National Cancer Institute, Bethesda, MD. Based on November 2017 SEER data submission, posted to the SEER web site on April 2018. Available from: https://seer.cancer.gov/csr/1975_2015/2018 [Last accessed on 18 Jul 2018].

4. Lucas MS, Barakat LP, Jones NL, Ulrich CM, Deatrick JA. Expectations for function and independence by childhood brain tumors survivors and their mothers. Narrat Inq Bioeth 2014;4:233-51.

5. van der Woude LL, Gorris MAJ, Halilovic A, Figdor CG, de Vries IJM. Migrating into the tumor: a roadmap for T cells. Trends Cancer 2017;3:797-808.

6. Garrido F, Perea F, Bernal M, Sánchez-Palencia A, Aptsiauri N, Ruiz-Cabello F. The escape of cancer from T cell-mediated immune surveillance: HLA class I loss and tumor tissue architecture. Vaccines 2017;5:7.

7. Carson MJ, Doose JM, Melchior B, Schmid CD, Ploix CC. CNS immune privilege: hiding in plain sight. Immunol Rev 2006;213:4865.

8. Rizvi NA, Hellmann MD, Snyder A, Kvistborg P, Makarov V, Havel JJ, Lee W, Yuan J, Wong P, Ho TS, Miller ML, Rekhtman N, Moreira AL, Ibrahim F, Bruggeman C, Gasmi B, Zappasodi R, Maeda Y, Sander C, Garon EB, Merghoub T, Wolchok JD, Schumacher 
TN, Chan TA. Mutational landscape determines sensitivity to PD-1 blockade in non-small cell lung cancer. Science 2015;348:124-8.

9. Supek F, Miñana B, Valcárcel J, Gabaldón T, Lehner B. Synonymous mutations frequently act as driver mutations in human cancers. Cell 2014;156:1324-35.

10. Topalian SL, Sznol M, McDermott DF, Kluger HM, Carvajal RD, Sharfman WH, Brahmer JR, Lawrence DP, Atkins MB, Powderly JD, Leming PD, Lipson EJ, Puzanov I, Smith DC, Taube JM, Wigginton JM, Kollia GD, Gupta A, Pardoll DM, Sosman JA, Hodi FS. Survival, durable tumor remission, and long-term safety in patients with advanced melanoma receiving nivolumab. J Clin Oncol 2014;32:1020-30.

11. Rizvi NA, Mazières J, Planchard D, Stinchcombe TE, Dy GK, Antonia SJ, Horn L, Lena H, Minenza E, Mennecier B, Otterson GA, Campos LT, Gandara DR, Levy BP, Nair SG, Zalcman G, Wolf J, Souquet P-J, Baldini E, Cappuzzo F, Chouaid C, Dowlati A, Sanborn R, Lopez-Chavez A, Grohe C, Huber RM, Harbison CT, Baudelet C, Lestini BJ, Ramalingam SS. Activity and safety of nivolumab, an anti-PD-1 immune checkpoint inhibitor, for patients with advanced, refractory squamous non-small-cell lung cancer (CheckMate 063): a phase 2, single-arm trial. Lancet Oncol 2015;16:257-65.

12. Alexandrov LB, Nik-Zainal S, Wedge DC, Aparicio SA, Behjati S, Biankin AV, Bignell GR, Bolli N, Borg A, Borresen-Dale AL, Boyault S, Burkhardt B, Butler AP, Caldas C, Davies HR, Desmedt C, Eils R, Eyfjord JE, Foekens JA, Greaves M, Hosoda F, Hutter B, Ilicic T, Imbeaud S, Imielinski M, Jager N, Jones DT, Jones D, Knappskog S, Kool M, Lakhani SR, Lopez-Otin C, Martin S, Munshi NC, Nakamura H, Northcott PA, Pajic M, Papaemmanuil E, Paradiso A, Pearson JV, Puente XS, Raine K, Ramakrishna M, Richardson AL, Richter J, Rosenstiel P, Schlesner M, Schumacher TN, Span PN, Teague JW, Totoki Y, Tutt AN, Valdes-Mas R, van Buuren MM, van 't Veer L, Vincent-Salomon A, Waddell N, Yates LR, Zucman-Rossi J, Futreal PA, McDermott U, Lichter P, Meyerson M, Grimmond SM, Siebert R, Campo E, Shibata T, Pfister SM, Campbell PJ, Stratton MR. Signatures of mutational processes in human cancer. Nature 2013;500:415-21.

13. Bouffet E, Larouche V, Campbell BB, Merico D, de Borja R, Aronson M, Durno C, Krueger J, Cabric V, Ramaswamy V, Zhukova N, Mason G, Farah R, Afzal S, Yalon M, Rechavi G, Magimairajan V, Walsh MF, Constantini S, Dvir R, Elhasid R, Reddy A, Osborn M, Sullivan M, Hansford J, Dodgshun A, Klauber-Demore N, Peterson L, Patel S, Lindhorst S, Atkinson J, Cohen Z, Laframboise R, Dirks P, Taylor M, Malkin D, Albrecht S, Dudley RW, Jabado N, Hawkins CE, Shlien A, Tabori U. Immune checkpoint inhibition for hypermutant glioblastoma multiforme resulting from germline biallelic mismatch repair deficiency. J Clin Oncol 2016;34:2206-11.

14. Lemos H, Huang L, Chandler PR, Mohamed E, Souza GR, Li L, Pacholczyk G, Barber GN, Hayakawa Y, Munn DH, Mellor AL. Activation of the STING adaptor attenuates experimental autoimmune encephalitis. J Immunol 2014;192:5571-8.

15. Noman MZ, Hasmim M, Messai Y, Terry S, Kieda C, Janji B, Chouaib S. Hypoxia: a key player in antitumor immune response. A review in the theme: cellular responses to hypoxia. Am J Physiol Cell Physiol 2015;309:C569-79.

16. Mantovani A, Sica A, Sozzani S, Allavena P, Vecchi A, Locati M. The chemokine system in diverse forms of macrophage activation and polarization. Trends Immunol 2004;25:677-86.

17. Chatzinikolaou G, Karakasilioti I, Garinis GA. DNA damage and innate immunity: links and trade-offs. Trends Immunol2014;35:429-35.

18. Woods D, Turchi JJ. Chemotherapy induced DNA damage response: convergence of drugs and pathways. Cancer Biol Ther 2013;14:379-89.

19. Kondo N, Takahashi A, Ono K, Ohnishi T. DNA damage induced by alkylating agents and repair pathways. J Nucleic Acids 2010;2010:543531.

20. Gasser S, Orsulic S, Brown EJ, Raulet DH. The DNA damage pathway regulates innate immune system ligands of the NKG2D receptor. Nature 2005;436:1186-90.

21. Liontos M, Anastasiou I, Bamias A, Dimopoulos MA. DNA damage, tumor mutational load and their impact on immune responses against cancer. Ann Transl Med 2016;4:264.

22. Torgovnick A, Schumacher B. DNA repair mechanisms in cancer development and therapy. Front Genet 2015;6:157.

23. Bibault JE, Tinhofer I. The role of next-generation sequencing in tumoral radiosensitivity prediction. Clin Transl Radiat Oncol 2017;3:16-20.

24. Conry RM, Westbrook B, McKee S, Norwood TG. Talimogene laherparepvec: first in class oncolytic virotherapy. Hum Vaccin Immunother 2018;14:839-46.

25. Lawler SE, Speranza M, Cho C, Chiocca E. Oncolytic viruses in cancer treatment: a review. JAMA Oncol 2017;3:841-9.

26. Lichty BD, Breitbach CJ, Stojdl DF, Bell JC. Going viral with cancer immunotherapy. Nat Rev Cancer 2014;14:559-67.

27. Gromeier M, Nair SK. Recombinant poliovirus for cancer immunotherapy. Ann Rev Med 2018;69:289-99.

28. Duke University. Phase 1b Study PVSRIPO for Recurrent Malignant Glioma in Children. ClinicalTrials.gov Identifier: NCT03043391.

29. Tejada S, Alonso M, Patiño A, Fueyo J, Gomez-Manzano C, Diez-Valle R. Phase I trial of DNX-2401 for diffuse intrinsic pontine glioma newly diagnosed in pediatric patients. Neurosurgery 2017; doi: 10.1093/neuros/nyx507.

30. Mayo Clinic. Wild-Type Reovirus in Combination With Sargramostim in Treating Younger Patients With High-Grade Relapsed or Refractory Brain Tumors. ClinicalTrials.gov Identifier: NCT02444546.

31. Waters AM, Johnston JM, Reddy AT, Fiveash J, Madan-Swain A, Kachurak K, Bag AK, Gillespie GY, Markert JM, Friedman GK. Rationale and design of a phase 1 clinical trial to evaluate HSV G207 alone or with a single radiation dose in children with progressive or recurrent malignant supratentorial brain tumors. Hum Gene Ther Clin Dev 2017;28:7-16.

32. University of Alabama at Birmingham. HSV G207 Alone or With a Single Radiation Dose in Children With Progressive or Recurrent Supratentorial Brain Tumors. ClinicalTrials.gov Identifier: NCT02457845.

33. Csatary LK, Bakács T. Use of newcastle disease virus vaccine (mth-68/h) in a patient with high-grade glioblastoma. JAMA 1999;281:1588-9.

34. Van Gool S, Lulei M, Schirrmacher V, Stuecker W. DIPG-10. Multimodal immunotherapy as part of multimodal treatment for DIPG. Neuro Oncol 2017;19:iv6-7. 
35. Brown MC, Holl EK, Boczkowski D, Dobrikova E, Mosaheb M, Chandramohan V, Bigner DD, Gromeier M, Nair SK. Cancer immunotherapy with recombinant poliovirus induces IFN-dominant activation of dendritic cells and tumor antigen-specific CTLs. Sci Transl Med 2017;9:eaan4220.

36. Desjardins A, Sampson JH, Vlahovic G, Peters KB, Randazzo D, Threatt S, Herndon JE, Bullock CA, Miller ES, Boulton S, Lally-Goss D, McSherry F, Lipp ES, Friedman AH, Friedman HS, Bigner DD, Gromeier M. Dose finding study of the intratumoral administration of the oncolytic polio/rhinovirus recombinant (PVSRIPO) against WHO grade IV malignant glioma (MG). J Clin Oncol 2017;35 suppl 15:e13533.

37. Markert JM, Razdan SN, Kuo HC, Cantor A, Knoll A, Karrasch M, Nabors LB, Markiewicz M, Agee BS, Coleman JM, Lakeman AD, Palmer CA, Parker JN, Whitley RJ, Weichselbaum RR, Fiveash JB, Gillespie GY. A phase 1 trial of oncolytic HSV-1, G207, given in combination with radiation for recurrent GBM demonstrates safety and radiographic responses. Mol Ther 2014;22:1048-55.

38. Clements D, Helson E, Gujar SA, Lee PW. Reovirus in cancer therapy: an evidence-based review. Oncolytic Virother 2014;3:69-82.

39. Samson A, Scott KJ, Taggart D, West EJ, Wilson E, Nuovo GJ, Thomson S, Corns R, Mathew RK, Fuller MJ, Kottke TJ, Thompson JM, Ilett EJ, Cockle JV, van Hille P, Sivakumar G, Polson ES, Turnbull SJ, Appleton ES, Migneco G, Rose AS, Coffey MC, Beirne DA, Collinson FJ, Ralph C, Alan Anthoney D, Twelves CJ, Furness AJ, Quezada SA, Wurdak H, Errington-Mais F, Pandha H, Harrington KJ, Selby PJ, Vile RG, Griffin SD, Stead LF, Short SC, Melcher AA. Intravenous delivery of oncolytic reovirus to brain tumor patients immunologically primes for subsequent checkpoint blockade. Sci Transl Med 2018;10:eaam7577.

40. Schirrmacher V. Fifty years of clinical application of newcastle disease virus: time to celebrate! Biomedicines 2016;4:16.

41. Griffiths DJ. Endogenous retroviruses in the human genome sequence. Genome Biol 2001;2:REVIEWS1017.

42. Yamashita M, Emerman M. Retroviral infection of non-dividing cells: old and new perspectives. Virology 2006;344:88-93.

43. Richardson AM, Collins SA, Inagaki A, Armstrong VL, Roussel M, Jolly D, Robbins DJ, Ayad N, Kasahara N. PDTM-19. TOCA 511 \& TOCA FC: pre-clinical proof of concept in medulloblastoma. Neuro Oncol 2017;19:vi193.

44. Robbins PD, Ghivizzani SC. Viral vectors for gene therapy. Pharmacol Ther 1998;80:35-47.

45. George LA, Sullivan SK, Giermasz A, Rasko JEJ, Samelson-Jones BJ, Ducore J, Cuker A, Sullivan LM, Majumdar S, Teitel J, McGuinn CE, Ragni MV, Luk AY, Hui D, Wright JF, Chen Y, Liu Y, Wachtel K, Winters A, Tiefenbacher S, Arruda VR, van der Loo JCM, Zelenaia O, Takefman D, Carr ME, Couto LB, Anguela XM, High KA. Hemophilia B gene therapy with a high-specific-activity factor IX variant. N Engl J Med 2017;377:2215-27.

46. Chiocca EA, Yu J, Phuphanich S, Lukas RV, Kumthekar P, Yang Y, Zhou Q, Buck JY, Deary A, Cai H, Barrett JA, Cooper LJN, Lebel FM. Expanded phase I study of intratumoral Ad-RTS-hIL-12 plus oral veledimex: tolerability and survival in recurrent glioblastoma. J Clin Oncol 2017;35 suppl 15:2044.

47. Ziopharm. A Study of Ad-RTS-hIL-12 + Veledimex in Pediatric Subjects With Brain Tumors or DIPG. ClinicalTrials.gov Identifier: NCT03330197.

48. Slamon D, Eiermann W, Robert N, Pienkowski T, Martin M, Press M, Mackey J, Glaspy J, Chan A, Pawlicki M, Pinter T, Valero V, Liu MC, Sauter G, von Minckwitz G, Visco F, Bee V, Buyse M, Bendahmane B, Tabah-Fisch I, Lindsay MA, Riva A, Crown J. Adjuvant trastuzumab in HER2-positive breast cancer. N Engl J Med 2011;365:1273-83.

49. Clynes RA, Towers TL, Presta LG, Ravetch JV. Inhibitory Fe receptors modulate in vivo cytotoxicity against tumor targets. Nat Med 2000;6:443-6.

50. Kute T, Lack CM, Willingham M, Bishwokama B, Williams H, Barrett K, Mitchell T, Vaughn JP. Development of Herceptin resistance in breast cancer cells. Cytometry A 2004;57:86-93.

51. Fiszman GL, Jasnis MA. Molecular mechanisms of trastuzumab resistance in HER2 overexpressing breast cancer. Int J Breast Cancer 2011;2011:352182.

52. Elamin YY, Rafee S, Toomey S, Hennessy BT. Immune effects of bevacizumab: killing two birds with one stone. Cancer Microenviron 2015;8:15-21.

53. Gururangan S, Fangusaro J, Poussaint TY, McLendon RE, Onar-Thomas A, Wu S, Packer RJ, Banerjee A, Gilbertson RJ, Fahey F, Vajapeyam S, Jakacki R, Gajjar A, Goldman S, Pollack IF, Friedman HS, Boyett JM, Fouladi M, Kun LE. Efficacy of bevacizumab plus irinotecan in children with recurrent low-grade gliomas - a pediatric brain tumor consortium study. Neuro Oncol 2014;16:310-7.

54. Cohen MH, Shen YL, Keegan P, Pazdur R. FDA drug approval summary: bevacizumab (Avastin) as treatment of recurrent glioblastoma multiforme. Oncologist 2009;14:1131-8.

55. Qaddoumi I, Kocak M, Pai-Panandiker A, Armstrong G, Wetmore C, Crawford J, Lin T, Boyett J, Kun L, Boop F, Merchant T, Ellison D, Gajjar A, Broniscer A. Phase II trial of erlotinib during and after radiotherapy in children with newly diagnosed high-grade gliomas. Front Oncol 2014;4:67.

56. Jakacki RI, Foley MA, Horan J, Wang J, Kieran MW, Bowers DC, Bouffet E, Zacharoulis S, Gill SC. Single-agent erlotinib versus oral etoposide in patients with recurrent or refractory pediatric ependymoma: a randomized open-label study. J Neurooncol 2016;129:131-8.

57. Kol A, van Scheltinga AT, Pool M, Gerdes C, de Vries E, de Jong S. ADCC responses and blocking of EGFR-mediated signaling and cell growth by combining the anti-EGFR antibodies imgatuzumab and cetuximab in NSCLC cells. Oncotarget 2017;8:45432-46.

58. Hassan SB, Sørensen JF, Olsen BN, Pedersen AE. Anti-CD40-mediated cancer immunotherapy: an update of recent and ongoing clinical trials. Immunopharmacol Immunotoxicol 2014;36:96-104.

59. Vonderheide RH, Glennie MJ. Agonistic CD40 antibodies and cancer therapy. Clin Cancer Res 2013;19:1035-43.

60. Pediatric Brain Tumor Consortium. Phase I Study of APX005M in Pediatric CNS Tumors. ClinicalTrials.gov Identifier: NCT03389802.

61. Tseng D, Volkmer JP, Willingham SB, Contreras-Trujillo H, Fathman JW, Fernhoff NB, Seita J, Inlay MA, Weiskopf K, Miyanishi M, Weissman IL. Anti-CD47 antibody-mediated phagocytosis of cancer by macrophages primes an effective antitumor T-cell response. Proc Natl Acad Sci U S A 2013;110:11103-8.

62. Gholamin S, Mitra SS, Feroze AH, Liu J, Kahn SA, Zhang M, Esparza R, Richard C, Ramaswamy V, Remke M, Volkmer AK, Willingham S, Ponnuswami A, McCarty A, Lovelace P, Storm TA, Schubert S, Hutter G, Narayanan C, Chu P, Raabe EH, Harsh G, Taylor MD, 
Monje M, Cho YJ, Majeti R, Volkmer JP, Fisher PG, Grant G, Steinberg GK, Vogel H, Edwards M, Weissman IL, Cheshier SH. Disrupting the CD47-SIRP $\alpha$ anti-phagocytic axis by a humanized anti-CD47 antibody is an efficacious treatment for malignant pediatric brain tumors. Sci Transl Med 2017;9:eaaf2968.

63. Bredel M, Pollack IF, Hamilton RL, James CD. Epidermal growth factor receptor expression and gene amplification in high-grade nonbrainstem gliomas of childhood. Clin Cancer Res 1999;5:1786-92.

64. Chandramohan V, Bao X, Keir ST, Pegram CN, Szafranski SE, Piao H, Wikstrand CJ, McLendon RE, Kuan CT, Pastan IH, Bigner DD. Construction of an immunotoxin, D2C7-(scdsFv)-PE38KDEL, targeting EGFRwt and EGFRvIII for brain tumor therapy. Clin Cancer Res 2013;19:4717-27.

65. Randazzo D, Desjardins A, Chandramohan V, Sampson JH, Peters KB, Vlahovic G, Threatt S, Herndon JE, Boulton S, Lally-Goss D, Healy P, Lipp ES, Friedman AH, Bigner DD. Phase 1 single-center, dose escalation study of D2C7-IT administered intratumorally via convection-enhanced delivery for adult patients with recurrent malignant glioma. J Clin Oncol 2017;35 suppl 15:e13532.

66. Chandramohan V, Bao X, Kato Kaneko M, Kato Y, Keir ST, Szafranski SE, Kuan CT, Pastan IH, Bigner DD. Recombinant anti-podoplanin (NZ-1) immunotoxin for the treatment of malignant brain tumors. Int J Cancer 2013;132:2339-48.

67. Rainov NG, Heidecke V. Long term survival in a patient with recurrent malignant glioma treated with intratumoral infusion of an IL4targeted toxin (NBI-3001). J Neurooncol 2004;66:197-201.

68. Kunwar S, Prados MD, Chang SM, Berger MS, Lang FF, Piepmeier JM, Sampson JH, Ram Z, Gutin PH, Gibbons RD, Aldape KD, Croteau DJ, Sherman JW, Puri RK. Direct intracerebral delivery of cintredekin besudotox (IL13-PE38QQR) in recurrent malignant glioma: a report by the Cintredekin Besudotox Intraparenchymal Study Group. J Clin Oncol 2007;25:837-44.

69. Sampson JH, Akabani G, Archer GE, Bigner DD, Berger MS, Friedman AH, Friedman HS, Herndon JE 2nd, Kunwar S, Marcus S, McLendon RE, Paolino A, Penne K, Provenzale J, Quinn J, Reardon DA, Rich J, Stenzel T, Tourt-Uhlig S, Wikstrand C, Wong T, Williams R, Yuan F, Zalutsky MR, Pastan I. Progress report of a phase I study of the intracerebral microinfusion of a recombinant chimeric protein composed of transforming growth factor (TGF)-alpha and a mutated form of the Pseudomonas exotoxin termed PE-38 (TP-38) for the treatment of malignant brain tumors. J Neurooncol 2003;65:27-35.

70. Luther N, Zhou Z, Zanzonico P, Cheung N-K, Humm J, Edgar MA, Souweidane MM. The potential of theragnostic 124I-8H9 convection-enhanced delivery in diffuse intrinsic pontine glioma. Neuro Oncol 2014;16:800-6.

71. Y-mAbs Therapeutics. Convection-Enhanced Delivery of 124I-8H9 for Patients With Non-Progressive Diffuse Pontine Gliomas Previously Treated With External Beam Radiation Therapy. ClinicalTrials.gov Identifier: NCT01502917.

72. Przepiorka D, Ko C-W, Deisseroth A, Yancey CL, Candau-Chacon R, Chiu H-J, Gehrke BJ, Gomez-Broughton C, Kane RC, Kirshner S, Mehrotra N, Ricks TK, Schmiel D, Song P, Zhao P, Zhou Q, Farrell AT, Pazdur R. FDA approval: blinatumomab. Clin Cancer Res 2015;21:4035-9.

73. Gedeon PC, Schaller TH, Chitneni SK, Choi BD, Kuan CT, Suryadevara CM, Snyder DJ, Schmittling RJ, Szafranski SE, Cui X, Healy P, Herndon JE, McLendon RE, Keir ST, Archer GE, Reap E, Sanchez-Perez L, Bigner DD, Sampson JH. A rationally designed fully human EGFRvIII:CD3-targeted bispecific antibody redirects human $\mathrm{T}$ cells to treat patient-derived intracerebral malignant glioma. Clin Cancer Res 2018; doi: 10.1158/1078-0432.CCR-17-0126.

74. Wu G, Diaz AK, Paugh BS, Rankin SL, Ju B, Li Y, Zhu X, Qu C, Chen X, Zhang J, Easton J, Edmonson M, Ma X, Lu C, Nagahawatte P, Hedlund E, Rusch M, Pounds S, Lin T, Onar-Thomas A, Huether R, Kriwacki R, Parker M, Gupta P, Becksfort J, Wei L, Mulder HL, Boggs K, Vadodaria B, Yergeau D, Russell JC, Ochoa K, Fulton RS, Fulton LL, Jones C, Boop FA, Broniscer A, Wetmore C, Gajjar A, Ding L, Mardis ER, Wilson RK, Taylor MR, Downing JR, Ellison DW, Zhang J, Baker SJ. The genomic landscape of diffuse intrinsic pontine glioma and pediatric non-brainstem high-grade glioma. Nat Genet 2014;46:444-50.

75. Topalian SL, Hodi FS, Brahmer JR, Gettinger SN, Smith DC, McDermott DF, Powderly JD, Carvajal RD, Sosman JA, Atkins MB, Leming PD, Spigel DR, Antonia SJ, Horn L, Drake CG, Pardoll DM, Chen L, Sharfman WH, Anders RA, Taube JM, McMiller TL, Xu H, Korman AJ, Jure-Kunkel M, Agrawal S, McDonald D, Kollia GD, Gupta A, Wigginton JM, Sznol M. Safety, activity, and immune correlates of anti-PD-1 antibody in cancer. N Engl J Med 2012;366:2443-54.

76. Brahmer JR, Tykodi SS, Chow LQ, Hwu WJ, Topalian SL, Hwu P, Drake CG, Camacho LH, Kauh J, Odunsi K, Pitot HC, Hamid O, Bhatia S, Martins R, Eaton K, Chen S, Salay TM, Alaparthy S, Grosso JF, Korman AJ, Parker SM, Agrawal S, Goldberg SM, Pardoll DM, Gupta A, Wigginton JM. Safety and activity of anti-PD-L1 antibody in patients with advanced cancer. N Engl J Med 2012;366:2455-65.

77. Reardon DA, Omuro A, Brandes AA, Rieger J, Wick A, Sepulveda J, Phuphanich S, de Souza P, Ahluwalia MS, Lim M, Vlahovic G, Sampson J. OS10.3 Randomized phase 3 study evaluating the efficacy and safety of nivolumab vs bevacizumab in patients with recurrent glioblastoma: CheckMate 143. Neuro Oncol 2017;19:iii21.

78. Francisco LM, Sage PT, Sharpe AH. The PD-1 pathway in tolerance and autoimmunity. Immunol Rev 2010;236:219-42.

79. Iwai Y, Ishida M, Tanaka Y, Okazaki T, Honjo T, Minato N. Involvement of PD-L1 on tumor cells in the escape from host immune system and tumor immunotherapy by PD-L1 blockade. Proc Natl Acad Sci U S A 2002;99:12293-7.

80. Nduom EK, Wei J, Yaghi NK, Huang N, Kong L-Y, Gabrusiewicz K, Ling X, Zhou S, Ivan C, Chen JQ, Burks JK, Fuller GN, Calin GA, Conrad CA, Creasy C, Ritthipichai K, Radvanyi L, Heimberger AB. PD-L1 expression and prognostic impact in glioblastoma. Neuro Oncol 2016;18:195-205.

81. Mahadevan N, Adeni A, Hammerman P, Awad M, Gandhi L, Sholl L. MA15.02 non-synonymous mutation burden in lung carcinoma is associated with durable clinical response to immune checkpoint blockade. J Thorac Oncol 2017;12:S428-9.

82. Zappasodi R, Merghoub T, Wolchok JD. Emerging concepts for immune checkpoint blockade-based combination therapies. Cancer Cell 2018;33:581-98.

83. Snyder A, Makarov V, Merghoub T, Yuan J, Zaretsky JM, Desrichard A, Walsh LA, Postow MA, Wong P, Ho TS, Hollmann TJ, Bruggeman C, Kannan K, Li Y, Elipenahli C, Liu C, Harbison CT, Wang L, Ribas A, Wolchok JD, Chan TA. Genetic basis for clinical response to CTLA-4 blockade in melanoma. N Engl J Med 2014;371:2189-99. 
84. Le DT, Uram JN, Wang H, Bartlett BR, Kemberling H, Eyring AD, Skora AD, Luber BS, Azad NS, Laheru D, Biedrzycki B, Donehower RC, Zaheer A, Fisher GA, Crocenzi TS, Lee JJ, Duffy SM, Goldberg RM, de la Chapelle A, Koshiji M, Bhaijee F, Huebner T, Hruban RH, Wood LD, Cuka N, Pardoll DM, Papadopoulos N, Kinzler KW, Zhou S, Cornish TC, Taube JM, Anders RA, Eshleman JR, Vogelstein B, Diaz LA Jr. PD-1 blockade in tumors with mismatch-repair deficiency. N Engl J Med 2015;372:2509-20.

85. Greenman C, Stephens P, Smith R, Dalgliesh GL, Hunter C, Bignell G, Davies H, Teague J, Butler A, Stevens C, Edkins S, O’Meara S, Vastrik I, Schmidt EE, Avis T, Barthorpe S, Bhamra G, Buck G, Choudhury B, Clements J, Cole J, Dicks E, Forbes S, Gray K, Halliday K, Harrison R, Hills K, Hinton J, Jenkinson A, Jones D, Menzies A, Mironenko T, Perry J, Raine K, Richardson D, Shepherd R, Small A, Tofts C, Varian J, Webb T, West S, Widaa S, Yates A, Cahill DP, Louis DN, Goldstraw P, Nicholson AG, Brasseur F, Looijenga L, Weber BL, Chiew YE, deFazio A, Greaves MF, Green AR, Campbell P, Birney E, Easton DF, Chenevix-Trench G, Tan MH, Khoo SK, Teh BT, Yuen ST, Leung SY, Wooster R, Futreal PA, Stratton MR. Patterns of somatic mutation in human cancer genomes. Nature 2007;446:153.

86. Hodges TR, Ott M, Xiu J, Gatalica Z, Swensen J, Zhou S, Huse JT, de Groot J, Li S, Overwijk WW, Spetzler D, Heimberger AB. Mutational burden, immune checkpoint expression, and mismatch repair in glioma: implications for immune checkpoint immunotherapy. Neuro Oncol 2017;19:1047-57.

87. Bristol-Myers Squibb. An Investigational Immuno-therapy Study of Nivolumab Compared to Temozolomide, Each Given With Radiation Therapy, for Newly-diagnosed Patients With Glioblastoma (GBM, a Malignant Brain Cancer) (CheckMate 498). ClinicalTrials.gov Identifier: NCT02617589.

88. Bristol-Myers Squibb. An Investigational Immuno-therapy Study of Temozolomide Plus Radiation Therapy With Nivolumab or Placebo, for Newly Diagnosed Patients With Glioblastoma (GBM, a Malignant Brain Cancer) (CheckMate548). ClinicalTrials.gov Identifier: NCT02667587.

89. Garber K. A new cancer immunotherapy suffers a setback. Science 2018;360:588.

90. Schaller TH, Sampson JH. Advances and challenges: dendritic cell vaccination strategies for glioblastoma. Expert Rev Vaccines 2017; 16:27-36.

91. Palucka K, Banchereau J. Dendritic-cell-based therapeutic cancer vaccines. Immunity 2013;39:38-48.

92. Banchereau J, Palucka K. Cancer vaccines on the move. Nat Rev Clin Oncol 2017;15:9.

93. Caruso DA, Orme LM, Neale AM, Radcliff FJ, Amor GM, Maixner W, Downie P, Hassall TE, Tang MLK, Ashley DM. Results of a phase 1 study utilizing monocyte-derived dendritic cells pulsed with tumor RNA in children and young adults with brain cancer. Neuro Oncol 2004;6:236-46.

94. Rutkowski S, De Vleeschouwer S, Kaempgen E, Wolff JEA, Kühl J, Demaerel P, Warmuth-Metz M, Flamen P, Van Calenbergh F, Plets C, Sörensen N, Opitz A, Van Gool SW. Surgery and adjuvant dendritic cell-based tumour vaccination for patients with relapsed malignant glioma, a feasibility study. Br J Cancer 2004;91:1656.

95. Lasky JL 3rd, Panosyan EH, Plant A, Davidson T, Yong WH, Prins RM, Liau LM, Moore TB. Autologous tumor lysate-pulsed dendritic cell immunotherapy for pediatric patients with newly diagnosed or recurrent high-grade gliomas. Anticancer Res 2013;33:2047-56.

96. De Vleeschouwer S, Fieuws S, Rutkowski S, Van Calenbergh F, Van Loon J, Goffin J, Sciot R, Wilms G, Demaerel P, Warmuth-Metz M, Soerensen N, Wolff JEA, Wagner S, Kaempgen E, Van Gool SW. Postoperative Adjuvant dendritic cell-based immunotherapy in patients with relapsed glioblastoma multiforme. Clin Cancer Res 2008;14:3098.

97. Cobbs CS, Harkins L, Samanta M, Gillespie GY, Bharara S, King PH, Nabors LB, Cobbs CG, Britt WJ. Human cytomegalovirus infection and expression in human malignant glioma. Cancer Res 2002;62:3347-50.

98. Prins RM, Cloughesy TF, Liau LM. Cytomegalovirus immunity after vaccination with autologous glioblastoma lysate. N Engl J Med 2008;359:539-41.

99. Batich KA, Reap EA, Archer GE, Sanchez-Perez L, Nair SK, Schmittling RJ, Norberg P, Xie W, Herndon JE 2nd, Healy P, McLendon RE, Friedman AH, Friedman HS, Bigner D, Vlahovic G, Mitchell DA, Sampson JH. Long-term survival in glioblastoma with cytomegalovirus pp65-targeted vaccination. Clin Cancer Res 2017;23:1898-909.

100. Mitchell DA, Batich KA, Gunn MD, Huang MN, Sanchez-Perez L, Nair SK, Congdon KL, Reap EA, Archer GE, Desjardins A, Friedman AH, Friedman HS, Herndon JE 2nd, Coan A, McLendon RE, Reardon DA, Vredenburgh JJ, Bigner DD, Sampson JH. Tetanus toxoid and CCL3 improve dendritic cell vaccines in mice and glioblastoma patients. Nature 2015;519:366-9.

101. University of California, San Francisco. H3.3K27M Peptide Vaccine for Children With Newly Diagnosed DIPG and Other Gliomas. ClinicalTrials.gov Identifier: NCT02960230.

102. Gary Archer Ph.D., Duke University. PEP-CMV in Recurrent MEdulloblastoma/Malignant Glioma (PRiME). ClinicalTrials.gov Identifier: NCT03299309.

103. Ian F. Pollack, M.D., University of Pittsburgh. A Pilot Study of Glioma Associated Antigen Vaccines in Conjunction With Poly-ICLC in Pediatric Gliomas. ClinicalTrials.gov Identifier: NCT01130077.

104. Pollack IF, Jakacki RI, Butterfield LH, Hamilton RL, Panigrahy A, Potter DM, Connelly AK, Dibridge SA, Whiteside TL, Okada H. Antigen-specific immune responses and clinical outcome after vaccination with glioma-associated antigen peptides and polyinosinicpolycytidylic acid stabilized by lysine and carboxymethylcellulose in children with newly diagnosed malignant brainstem and nonbrainstem gliomas. J Clin Oncol 2014;32:2050-8.

105. Pollack IF, Jakacki RI, Butterfield LH, Hamilton RL, Panigrahy A, Normolle DP, Connelly AK, Dibridge S, Mason G, Whiteside TL, Okada H. Immune responses and outcome after vaccination with glioma-associated antigen peptides and poly-ICLC in a pilot study for pediatric recurrent low-grade gliomas. Neuro Oncol 2016;18:1157-68.

106. Ascarateil S, Puget A, Koziol ME. Safety data of Montanide ISA 51 VG and Montanide ISA 720 VG, two adjuvants dedicated to human therapeutic vaccines. J Immunother Cancer 2015;3:P428.

107. Ott PA, Hu Z, Keskin DB, Shukla SA, Sun J, Bozym DJ, Zhang W, Luoma A, Giobbie-Hurder A, Peter L, Chen C, Olive O, Carter TA, Li S, Lieb DJ, Eisenhaure T, Gjini E, Stevens J, Lane WJ, Javeri I, Nellaiappan K, Salazar AM, Daley H, Seaman M, Buchbinder EI, 
Yoon CH, Harden M, Lennon N, Gabriel S, Rodig SJ, Barouch DH, Aster JC, Getz G, Wucherpfennig K, Neuberg D, Ritz J, Lander ES, Fritsch EF, Hacohen N, Wu CJ. An immunogenic personal neoantigen vaccine for patients with melanoma. Nature 2017;547:217-21.

108. Kruse CA, Cepeda L, Owens B, Johnson SD, Stears J, Lillehei KO. Treatment of recurrent glioma with intracavitary alloreactive cytotoxic T lymphocytes and interleukin-2. Cancer Immunol Immunother 1997;45:77-87.

109. Plautz GE, Barnett GH, Miller DW, Cohen BH, Prayson RA, Krauss JC, Luciano M, Kangisser DB, Shu S. Systemic T cell adoptive immunotherapy of malignant gliomas. J Neurosurg 1998;89:42-51.

110. Exley MA, Friedlander P, Alatrakchi N, Vriend L, Yue S, Sasada T, Zeng W, Mizukami Y, Clark J, Nemer D, LeClair K, Canning C, Daley H, Dranoff G, Giobbie-Hurder A, Hodi FS, Ritz J, Balk SP. Adoptive transfer of invariant NKT cells as immunotherapy for advanced melanoma: a phase I clinical trial. Clin Cancer Res 2017;23:3510-9.

111. Maude SL, Frey N, Shaw PA, Aplenc R, Barrett DM, Bunin NJ, Chew A, Gonzalez VE, Zheng Z, Lacey SF, Mahnke YD, Melenhorst JJ, Rheingold SR, Shen A, Teachey DT, Levine BL, June CH, Porter DL, Grupp SA. Chimeric antigen receptor T cells for sustained remissions in leukemia. N Engl J Med 2014;371:1507-17.

112. Schuster SJ, Svoboda J, Chong EA, Nasta SD, Mato AR, Anak O, Brogdon JL, Pruteanu-Malinici I, Bhoj V, Landsburg D, Wasik M, Levine BL, Lacey SF, Melenhorst JJ, Porter DL, June CH. Chimeric antigen receptor T cells in refractory B-cell lymphomas. N Engl J Med 2017;377:2545-54.

113. Ahmed N, Brawley V, Hegde M, Bielamowicz K, Kalra M, Landi D, Robertson C, Gray TL, Diouf O, Wakefield A, Ghazi A, Gerken C, Yi Z, Ashoori A, Wu MF, Liu H, Rooney C, Dotti G, Gee A, Su J, Kew Y, Baskin D, Zhang YJ, New P, Grilley B, Stojakovic M, Hicks J, Powell SZ, Brenner MK, Heslop HE, Grossman R, Wels WS, Gottschalk S. Her2-specific chimeric antigen receptor-modified virusspecific T cells for progressive glioblastoma: a phase 1 dose-escalation trial. JAMA Oncol 2017;3:1094-101.

114. Brown CE, Alizadeh D, Starr R, Weng L, Wagner JR, Naranjo A, Ostberg JR, Blanchard MS, Kilpatrick J, Simpson J, Kurien A, Priceman SJ, Wang X, Harshbarger TL, D'Apuzzo M, Ressler JA, Jensen MC, Barish ME, Chen M, Portnow J, Forman SJ, Badie B. Regression of glioblastoma after chimeric antigen receptor T-cell therapy. N Engl J Med 2016;375:2561-9.

115. O’Rourke DM, Nasrallah MP, Desai A, Melenhorst JJ, Mansfield K, Morrissette JJD, Martinez-Lage M, Brem S, Maloney E, Shen A, Isaacs R, Mohan S, Plesa G, Lacey SF, Navenot JM, Zheng Z, Levine BL, Okada H, June CH, Brogdon JL, Maus MV. A single dose of peripherally infused EGFRvIII-directed CAR T cells mediates antigen loss and induces adaptive resistance in patients with recurrent glioblastoma. Sci Transl Med 2017;9:eaaa0984.

116. Fuda Cancer Hospital, Guangzhou. CAR-T Cell Immunotherapy for EphA2 Positive Malignant Glioma Patients. ClinicalTrials.gov Identifier: NCT02575261.

117. Long AH, Haso WM, Shern JF, Wanhainen KM, Murgai M, Ingaramo M, Smith JP, Walker AJ, Kohler ME, Venkateshwara VR, Kaplan RN, Patterson GH, Fry TJ, Orentas RJ, Mackall CL. 4-1BB costimulation ameliorates T cell exhaustion induced by tonic signaling of chimeric antigen receptors. Nat Med 2015;21:581-90.

118. Fangusaro JR, Onar-Thomas A, Young-Poussaint T, Wu S, Ligon AH, Lindeman NI, Banerjee A, Packer R, Kilburn LB, Pollack I, Jakacki R, Qaddoumi IA, Fisher PG, Dhall G, Baxter PA, Kreissman SG, Doyle LA, Smith MA, Dunkel IJ, Fouladi M. A phase II prospective study of selumetinib in children with recurrent or refractory low-grade glioma (LGG): a pediatric brain tumor consortium (PBTC) study. J Clin Oncol 2017;35 suppl 15:10504. 